\title{
CISH Gene
}

National Cancer Institute

\section{Source}

National Cancer Institute. CISH Gene. NCI Thesaurus. Code C24299.

This gene plays a role in cellular signaling. 